AperTO - Archivio Istituzionale Open Access dell'Università di Torino

\title{
POLLEN CONCENTRATIONS AND PREVALENCE OF ASTHMA AND ALLERGIC RHINITIS IN ITALY: EVIDENCE FROM THE GEIRD STUDY
}

\section{This is the author's manuscript}

Original Citation:

Availability:

This version is available http://hdl.handle.net/2318/1623022

since 2017-01-25T16:50:32Z

Published version:

DOI:10.1016/j.scitotenv.2017.01.168

Terms of use:

Open Access

Anyone can freely access the full text of works made available as "Open Access". Works made available under a Creative Commons license can be used according to the terms and conditions of said license. Use of all other works requires consent of the right holder (author or publisher) if not exempted from copyright protection by the applicable law. 
This Accepted Author Manuscript (AAM) is copyrighted and published by Elsevier. It is posted here by agreement between Elsevier and the University of Turin. Changes resulting from the publishing process - such as editing, corrections, structural formatting, and other quality control mechanisms - may not be reflected in this version of the text. The definitive version of the text was subsequently published in SCIENCE OF THE TOTAL ENVIRONMENT, 584-585 (15 aprile 2017), 2017, 10.1016/j.scitotenv.2017.01.168.

You may download, copy and otherwise use the AAM for non-commercial purposes provided that your license is limited by the following restrictions:

(1) You may use this AAM for non-commercial purposes only under the terms of the CC-BY-NC-ND license.

(2) The integrity of the work and identification of the author, copyright owner, and publisher must be preserved in any copy.

(3) You must attribute this AAM in the following format: Creative Commons BY-NC-ND license (http://creativecommons.org/licenses/by-nc-nd/4.0/deed.en), 10.1016/j.scitotenv.2017.01.168

The publisher's version is available at:

http://linkinghub.elsevier.com/retrieve/pii/S0048969717301857

When citing, please refer to the published version.

Link to this full text:

http://hdl.handle.net/2318/1623022 
1 Title

2 POLLEN CONCENTRATIONS AND PREVALENCE OF ASTHMA AND ALLERGIC

3 RHINITIS IN ITALY: EVIDENCE FROM THE GEIRD STUDY.

4

5 Authors

6 Pierpaolo Marchetti ${ }^{1}$, Giancarlo Pesce ${ }^{1}$, Simona Villani ${ }^{2}$, Leonardo Antonicelli ${ }^{3}$, Renato

7 Ariano $^{4}$, Francesco Attena ${ }^{5}$, Roberto Bono ${ }^{6}$, Valeria Bellisario ${ }^{6}$, Alessandro Fois ${ }^{7}$, Nadia

8 Gibelli $^{8}$, Morena Nicolis ${ }^{9}$, Mario Olivieri ${ }^{10}$, Pietro Pirina ${ }^{7}$, Eugenio Scopano ${ }^{11}$, Consolata

9 Siniscalco ${ }^{12}$, Giuseppe Verlato ${ }^{1}$, Alessandro Marcon¹.

\section{Affiliations}

1 Unit of Epidemiology and Medical Statistics, Department of Diagnostics and Public

13 Health, University of Verona, Verona, Italy

142 Unit of Biostatistics and Clinical Epidemiology, Department of Public Health, 15 Experimental and Forensic Medicine, University of Pavia, Italy

163 Allergy Unit, Department of Internal Medicine, Azienda Ospedaliero-Universitaria

17 Ospedali Riuniti, Ancona, Italy

184 Allergologia, Azienda Sanitaria Locale 1, Imperiese (IM), Italy.

195 Department of Experimental Medicine, II University of Naples, Naples, Italy

206 Department of Public Health and Pediatrics, University of Turin, Turin, Italy

217 Unit of Lung Disease - Department of Clinical and Experimental Medicine - , University

22 of Sassari, Sassari, Italy 
238 U.O.C. di Medicina del Lavoro, Sezione di Allergologia. Fondazione Salvatore Maugeri, 24 Pavia, Italy

9 Unit of Hygiene and Preventive, Environmental and Occupational Medicine,

Department of Diagnostics and Public Health, University of Verona, Verona, Italy

2710 Unit of Occupational Medicine, University Hospital of Verona, Verona, Italy

2811 Air pollution Unit, Agenzia Regionale per la Protezione Ambientale Campania 29 (ARPAC), Caserta

12 Department of Life Sciences and Systems Biology - University of Turin, Turin, Italy

Corresponding Author:

PhD Pierpaolo Marchetti

Università degli Studi di Verona

36 Istituti biologici II, strada le Grazie 8, Verona, Italy

Tel.: +390458027656

Funding: The GEIRD project was funded by: the Cariverona Foundation, the Italian Ministry of Health, Chiesi Farmaceutici, and the Italian Medicines Agency (AIFA). The funders had no role in study design, data collection and analysis, decision to publish, or preparation of the manuscript. 


\section{ABSTRACT}

Background: Pollen exposure has acute adverse effects on sensitized individuals. Information on the prevalence of respiratory diseases in areas with different pollen concentrations is scanty.

Aim: We performed an ecologic analysis to assess whether the prevalence of allergic rhinitis and asthma in young adults varied across areas with different pollen concentrations in Italy.

Methods: A questionnaire on respiratory diseases was delivered to random samples of 2044 year-old subjects from six centers in 2005-2010. Data on the daily air concentrations of 7 major allergologic pollens (Poaceae, Urticaceae, Oleaceae, Cupressaceae, Coryloideae, Betula and Ambrosia) were collected for 2007-2008. Center-specific pollen exposure indicators were calculated, including the average number of days per year with pollens above the low or high concentration thresholds defined by the Italian Association of Aerobiology. Associations between pollen exposure and disease prevalence, adjusted for potential confounders, were estimated using logistic regression models with center as a random-intercept.

Results: Overall, 8834 subjects (56.8\%) filled in the questionnaire. Allergic rhinitis was significantly less frequent in the centers with longer periods with high concentrations of at least one (OR per 10 days $=0.989,95 \% \mathrm{Cl}: 0.979-0.999)$ or at least two pollens $(\mathrm{OR}=0.974,95 \% \mathrm{Cl}: 0.951-0.998)$; associations with the number of days with at least one $(\mathrm{OR}=0.988,95 \% \mathrm{Cl}: 0.972-1.004)$ or at least two (OR=0.985, 95\%Cl: $0.970-1.001)$ pollens above the low thresholds were borderline significant. Asthma prevalence was not associated with pollen concentrations. 
Conclusions: Our study does not support that the prevalence of allergic rhinitis and asthma

71 is greater in centers with higher pollen concentrations. It is not clear whether the observed ecologic associations hold at the individual level.

73

74

\section{Highlights}

- The chronic effects of pollens on allergic disease prevalence are poorly known

- We calculated center-specific indicators of long-term pollen exposure

- We studied if pollen levels are related to allergic rhinitis and asthma in Italy

- Allergic rhinitis was less frequent in centers with higher pollen loads

80

- There was no ecologic association of pollen exposure with asthma prevalence

81

82

Keywords (max 6)

84

Aeroallergen, adult, allergy, ecologic study, public health, respiratory. 


\section{INTRODUCTION}

Asthma and rhinitis are allergic respiratory diseases affecting, respectively, 5-15\% and 20 30\% of adults in Europe (Bauchau and Durham, 2004; Jarvis et al. 2012). The prevalence of both diseases shows great heterogeneity both between and within countries (Burney et al., 1994; Björnsson et al., 1994). Geo-climatic factors seem to account for part of this variability (Pesce et al. 2016). Climatic and meteorological conditions influence the regional flora and intensity of pollination, the dispersion of pollens and the duration of the pollen season (Latorre and Caccavari,2009, Mandrioli and Negrini in D'Amato,1991). Climate change may be in part responsible for the observed increases in asthma and allergic rhinitis prevalence in the last decade (Zanolin et al., 2004, de Marco et al. 2012), possibly through its effects of altering pollination (De Sario et al., 2013; D'Amato at al., 2014).

Exposure to pollens and other aeroallergens may cause allergy, which is a hyperreactivity reaction of the respiratory tract and eye conjunctiva mediated by immunological (mostly IgE-dependent) inflammation. In sensitized individuals, exposure to pollens leads to release of bioactive molecules such as histamine and lipid mediators that can cause smooth muscle contraction, increased vascular permeability, mucus secretion, and attract inflammatory cells (Plotz et al. 2004, Bernstein et al. 2016).

Pollens are one of several environmental factors that trigger symptoms of respiratory allergic diseases, along with meteorological conditions (extreme temperatures, thunderstorms) and chemical air pollutants (D’Amato et al. 2000; Celenza et al. 1996). Nonetheless few studies have investigated whether the prevalence of respiratory diseases varies across areas with different airborne pollen concentrations. All published studies investigated children (Silverberg et al. 2015; Burr et al., 2003; Yoshida et al., 2013). Inconsistent results from these studies showed either positive, null or negative associations between pollen concentrations and respiratory diseases, which may partly 
112 relate to the different populations and age groups examined, as well as to the different

113 vegetation and climatic conditions of the geographical areas.

114 The aim of this ecologic study is to describe the cross-sectional relationship between

115 annual concentrations of major allergologic pollens and the prevalence of allergic rhinitis

116 and asthma in the Italian centers participating in the GEIRD (Gene Environment

117 Interactions in Respiratory Diseases) study. 


\section{METHODS}

120

\section{Study design}

The phase one of the GEIRD multicenter study had a cross sectional design. Three thousands subjects of the Italian young adult general population aged 20-44 years (male to female ratio equal to 1) were selected from six centers between 2005 and 2010 (de Marco et al., 2010). Three centers (Turin, Pavia and Verona), in northern Italy, have a subcontinental climate (Köppen classification: CFA). The other three centers (Ancona, Sassari and Salerno) are coastal cities in central, insular and southern Italy respectively, and they are characterized by a mediterranean climate (Köppen classification: CSA). The subcontinental zone has a lower annual average temperature and a higher annual temperature range than the mediterranean zone (Pesce et al. 2016).

\section{Questionnaire and outcomes}

A brief postal questionnaire was self-administered for up to three times. In the case of final non response, a phone interview was carried out. The questionnaire (available at www.geird.org) investigated respiratory symptoms and diseases, socio-economic factors, smoking habits and exposure to vehicular traffic. The questions were derived from the European Community Respiratory Health Survey (de Marco et al., 1999). Each center obtained approval from the Ethics committee. All participants were fully informed about all aspects of the research project and consented to take part in the survey. A subject was considered to have:

- Allergic rhinitis if he/she answered "yes" to the question: "Do you have any nasal allergies including hay fever?".

- Asthma if he/she answered "yes" to both questions: "Have you ever had asthma?" and "Was this confirmed by a doctor?". 


\section{Pollen data}

Data on the daily air concentrations of seven pollens from five vegetal families (Poaceae, Urticaceae, Oleaceae, Cupressaceae), one subfamily (Coryloideae), and two genera (Betula and Ambrosia) were collected from local monitoring stations. The monitoring stations were within city centers, with the exception of Salerno, which had no local monitoring station. In this case we used data from the closest station (Napoli Portici) to derive pollen indicators (see graphical abstract, left panel). All the monitoring stations used a volumetric sampler of the Hirst type. The device consists of a pump which operates continuously for seven days and is calibrated to aspirate $10 \mathrm{l} / \mathrm{min}$ of air $\left(14.4 \mathrm{~m}^{3}\right)$ in $24 \mathrm{~h}$. The air is directed on a sampling surface constituted by a metallic drum which rotates at the speed of $2 \mathrm{~mm} / \mathrm{h}$, on which a plastic adhesive tape of silicone oil retains airborne particles. After seven days, the sampling drum with the adherent atmospheric particles is cut into fragments corresponding to the monitoring days. Each fragment is placed on a slide and covered with glycerin jelly mixed with basic fuchsine (Odgen et al. 1974) and examined under a microscope at $400 x$ magnification. The daily pollen concentration is determined as the number of pollen grains per cube meter of air (grains $\left./ \mathrm{m}^{3}\right)$.

Missing data in the time-series of pollen concentrations were considered to be nonrandomly allocated over time, since they could be generated by temporary instrumental breakdowns and maintenance. For this reason we decided to input them using the kNearest Neighbor algorithm (Fix and Hodges, 1951; Dixon, 1979). This algorithm assigns missing values based on their similarity to $\mathrm{k}$ non-missing values according to a Euclidean distance function. In our data, we set k=9 and we implemented the similarity function accounting for year, month, day, and calendar day. 


\section{Ecologic indicators of pollen exposure}

170 For each pollen taxa and for each center, we calculated the number of days, over a

171 calendar year, when pollen concentrations were above the low and high concentration

172 thresholds defined by the Italian Aerobiological Monitoring Network (Rete Italiana di Monitoraggio in Aerobiologia) of the Italian Association of Aerobiology (Associazione

174 Italiana di Aerobiologia) [http://www.ilpolline.it/]. Low and high thresholds in grains $/ \mathrm{m}^{3}$ are: Poaceae, 0.6 and 30; Urticaceae, 2 and 70; Oleaceae, 0.6 and 25; Cupressaceae, 4 and 90; Coryloideaeand Betula, 0.6 and 50; and Ambrosia, 0.1 and 25. We also computed the number of days, over a calendar year, when the concentrations of at least one and at least two pollens were above the low and high thresholds, respectively. Finally, we calculated "pollen intensity" as the sum of daily concentrations over a calendar year.

In the main analysis, center-specific proxy indicators of long-term pollen exposure were obtained by averaging the previously mentioned indicators over years 2007 and 2008 , which is an intermediate period during questionnaire data collection. However, under the hypothesis that self-reporting of allergic diseases may be influenced by the level of symptoms at the time of participation, alternative exposure indicators were calculated using daily data from the years of questionnaire administration in each center (ranging from 2005-2006 in Ancona to 2009-2010 in Turin, see supplementary figure S1) and used for sensitivity analysis.

\section{Statistical analysis}

. The associations (OR with 95\% Confidence Interval, 95\%Cl) between the pollen exposure indicators and the prevalence of allergic rhinitis and asthma were assessed using two-level logistic regression models, with center as a random intercept. All the 
193 analyses were adjusted for gender, age (mean centered), smoking habits (non-smokers, 194 ex-smokers, smokers with $<15$ cigarette pack-years, and smokers with $\geq 15$ pack-years), 195 education level (lower school, high school, degree), heavy traffic near home (never/rare, 196 frequent/constant), and climatic zone (subcontinental, mediterranean). To improve the 197 comparability across study centers, we also adjusted for the following design variables: 198 season of response, type of contact for questionnaire administration (mail, phone), 199 percentile rank of response (mean centered). The latter was included to account for 200 differences in response rates between centers [de Marco et al., 1994] The analysis on 201 asthma was also adjusted for the presence of allergic rhinitis. 
Overall, 8834 subjects filled in the questionnaire with a $56.8 \%$ of response (range: $37.1 \%$ Pavia $-67.7 \%$ Verona), $47.5 \%$ of them were males, and the median age was 35.2 years (Interquartile range: 11.8 years). Subjects from the mediterranean zone were more likely to be males, young, smokers and exposed to high traffic levels than subjects from the subcontinental zone (supplementary table S1).

The crude prevalence of diseases by center and climatic zone is shown in figure 1. Allergic rhinitis was more frequent in the mediterranean zone with respect to the subcontinental zone, $27.6 \%$ vs $25.3 \%(p=0.02)$. Across centers, the highest prevalence was in Salerno (29.0\%; 95\%Cl: 26.9-31.1\%) and the lowest in Verona (24.4\%; 95\%Cl: $22.5-26.5 \%$. Similarly, asthma prevalence was higher in the mediterranean than in the subcontinental zone (11.3\% vs $9.2 \%, \mathrm{p}=0.001)$ and it ranged from $8.3 \%(95 \% \mathrm{Cl}: 6.7-10.2 \%)$ in Pavia to $12.5 \%(95 \% \mathrm{Cl}: 10.7-14.4 \%)$ in Sassari.

Pollen concentrations in 2007-2008 for each center are shown in supplementary figure S2. Poaceae, Oleaceae and Cupressaceae, and lower for Betula and Ambrosia. The number of days with specific pollens above the low threshold were not significantly associated with the prevalence of allergic rhinitis (table 2); however, we found consistent negative associations (ORs below 1) of the number of days with high concentrations and pollen intensities with allergic rhinitis. In particular, these associations were statistically significant in the case of Poaceae (OR=0.977, $p=0.024$, for days with high concentrations; OR=0.983, $p=0.025$, for pollen intensity) and Cupressaceae (OR=0.996, $p=0.047$ for 
229 pollen intensity) (table 2). When looking at exposure indicators based on concentrations of 230 at least one or two pollens (figure 3), we found that centers with a longer period with high 231 concentrations had significantly less allergic rhinitis: disease prevalence was $1.1 \%$ and $2322.6 \%$ lower per 10 more days per year with high concentrations of at least one (OR=0.989, $233 \mathrm{p}=0.024)$ or at least two pollens $(\mathrm{OR}=0.974, \mathrm{p}=0.028)$, respectively. The associations for 234 the number of days with pollens above the low threshold were negative and borderline 235 significant (figure 3).

236 The associations between pollen exposure indicators and asthma were not consistent 237 (ORs were both greater and lower than 1), and none was statistically significant (table 2 238 and figure 3).

239 The sensitivity analyses performed using the indicators calculated over the specific years 240 of questionnaire administration confirmed the main analyses (supplementary Figure S3), 241 although there were some shifts in statistical significance in pollen-specific associations 242 (supplementary tables S3 and S4). 
In this cross-sectional multicenter study we report evidence on the ecologic associations between pollen exposure indicators and the prevalence of allergic respiratory diseases in young adults from the general Italian population. Our disease definitions were based on widely used questions in international epidemiological surveys such as ECRHS (Burney et al., 1994) or $\mathrm{GA}_{2} \mathrm{LEN}$ (Björnsson et al., 1994). We were able to account for many individual determinants that are known risk factors for allergic respiratory disease and that may have confounded the associations.

Overall, our findings indicate that the centers with a higher pollen load (i.e. days with high concentrations and pollen intensities) had a lower prevalence of allergic rhinitis, and this result was fairly consistent across the different analyses carried out. The presence (i.e. concentrations above the low thresholds) of specific pollens was not consistently associated with the prevalence of allergic rhinitis, although borderline significant negative associations of the number of days with at least one/two pollens suggest a lack of statistical power.

The fact that the centers with a higher pollen load had a lower prevalence of allergic rhinitis may seem counterintuitive, because of the well-known adverse short-term effects of aeroallergens, which induce nasal and conjunctival symptoms in sensitized subjects, increase hospital and emergency room admissions for asthma, and even respiratory and cardiovascular mortality (Bono et al. 2016; Brunekreef et al., 2000; Caillaud et al., 2014; Cakmak et al., 2012; Cirera et al. 2012; Eriksson and Holmen, 1996; Sakaida et al., 2014; Tobias et al. 2004). However, data on the long-term effect of pollens on the prevalence of allergic diseases are scarce and inconsistent. Our findings on adults are in agreement with an ecologic analysis on children within the ISAAC study (Burr et al., 2003), where the prevalence of allergic rhinitis was inversely associated with pollen exposure. The authors hypothesized that childhood exposure to high pollen concentrations might give some 
271 protection against respiratory allergy. This mechanism has also been proposed to explain 272 the induction of tolerance to perennial allergens in children (Ownby et al., 2003). On the 273 other hand, another study performed in the US found a positive association between total pollen counts and hay fever in children (Silverberg et al., 2015). The lack of a positive relationship between pollens and rhinitis may also entail that other risk factors, such as exposure to perennial allergens, are important. About half of allergic rhinitis patients are sensitized to house dust mites, even if they only have a seasonal disease, and questionnaire definitions are unable to disentangle between seasonal and perennial rhinitis in the absence of clinical data (Olivieri et al., 2002).

To our knowledge, only one ecologic study in Japan assessed the long-term association between pollens and asthma (Yoshida et al., 2013). It documented a positive association between cedar pollen counts and childhood asthma prevalence. In our study on adults, there was no association between pollen concentrations and asthma prevalence. In a recent study on the same population, we reported that there is a substantial variability of asthma prevalence in Italy, and that this variability can be explained to a large extent by a "climate indicator" obtained by factor analysis on data from all 110 main Italian cities (Pesce et al., 2016). In Italy, asthma prevalence is greater in areas where annual temperatures are higher and temperature ranges are smaller, which are typical features of the mediterranean climate (de Marco, 2002; Zanolin et al. 2004; Pesce et al., 2016). The effect of climate may be partly related to the levels of perennial allergens, as indoor levels of house dust mite allergens are lower in areas with colder winters (Zock et al., 2006), but dietary and lifestyle determinants may also have a role (Pesce et al. 2016).

We observed a distribution of pollen concentrations that is consistent with the pattern of vegetation in the country. Oleaceae (e.g. olive, ash, jasmine) and Cupressaceae (e.g. cypress) are typical of the temperate and warm region, whereas Betula (birch) and Ambrosia (ragweed) are more common in northern Italy. Poaceae (e.g. grass) and 
Urticaceae (e.g. nettle), the most common herbaceous families in Italy, are spread all over the peninsula, given their ability to grow in very different climatic conditions. Coryloideae (e.g. hornbeam, hophornbeam, and hazel) are mainly spread in the central and northern regions (Pre-Alps and Apennines). Among the indicators calculated, the number of days with pollens above the low thresholds represents the presence of measurable pollen levels during a year, under the hypothesis that even small pollen concentrations may affect disease prevalence at the population level. On the other hand, the number of days with high concentrations and pollen intensity are proxies of pollen load especially during the pollination season.

There was agreement between the analyses based on pollen data from 2007-08 and the analyses of data matched to the years of questionnaires administration, supporting that the results are robust to the method used to derive pollen exposure indicators. Also, the analyses based on pollen-specific concentrations and on concentrations of any pollen type were in a relative agreement. Differences in statistical significance may be explained by the low power due to the small number of centers included.

In the interpretation of our study findings, caution should be used. Diseases were defined using simple questionnaire items, since no clinical or laboratory data were available, and we had no information on the confirmation of allergic rhinitis by a doctor. Nonetheless, Olivieri et al. have documented that atopy is present among most (79\%) of subjects reporting allergic rhinitis, and only in a minority $(21 \%)$ of subjects who do not report allergic rhinitis (Olivieri et al., 2002). The ecologic associations observed at the center level may not reflect biologic associations at the individual level (the "ecologic fallacy", Rothman et al., 2008). In particular, our study was unable to consider the spatial variability in pollen distribution within centers. As a consequence, we have no direct evidence to test the hypothesis that a more exposed individual is more likely to have the disease. As we only had data from a small number of centers, we had limited power to investigate center-level 
323 variables (such as pollen concentrations), we could only study one center-level variable at 324 a time, and we had to assume that these variables had linear effects on log odds of 325 disease. Since we had no data on air pollution exposure, we adjusted the analyses for 326 self-reported exposure to traffic. Besides, we acknowledge that using data from Napoli 327 Portici to derive pollen indicators for Salerno may have introduced further exposure 328 misclassification (Katelaris et al., 2004).

329 In conclusion, evidence from this study does not support that allergic rhinitis and asthma 330 are more frequent in centers with a greater pollen concentration. This suggests that, while 331 pollen exposure is known to trigger acute effects in sensitized individuals, allergen 332 sensitization and the development of allergic diseases may be less influenced by living in 333 areas with a greater pollen concentration. Whether these ecologic associations hold at the 334 individual level is still unknown. 


\section{ACKNOWLEDGMENTS}

338 Data on pollen concentrations were provided by:

- Dipartimento di Sanità Pubblica e Medicina di Comunità, Sez. Igiene MAPO, Strada Le Grazie 8, Verona; Azienda Ospedaliera Universitaria Integrata di Verona, Servizio di Medicina del Lavoro, P.le L.A. Scuro, Verona;

- Fondazione Salvatore Maugeri, Via Salvatore Maugeri, 10 Pavia;

- Dipartimento di Scienze della Vita e Biologia dei Sistemi, Università di Torino, Viale Mattioli, 25, Torino;

- SOD Allergologia, Azienda Ospedaliero Universitaria Ospedali Riuniti, Ospedale Torrette 71, V. Conca, Ancona;

- Cattedra di Pneumologia, Facoltà di Medicina e Chirurgia, Università di Sassari, Viale San Pietro, Sassari;

- ARPAC, Agenzia Regionale Protezione Ambientale della Campania, Dipartimento di Caserta, Area Analitica Laboratorio Multisito Inquinamento Atmosferico (NA-CE) e Biomonitoraggio Regionale, Corso Giannone 44, 81100 Caserta.

Daily data on pollen concentrations for the years described in figure $\mathrm{S} 1$ are available for research purposes upon approval of the GEIRD Steering Committee, in line with the data sharing principle of the GEIRD study (www.geird.org), and the previously mentioned institutions. For data queries please contact the corresponding author. 


\section{REFERENCES}

Bauchau V, Durham SR. Prevalence and rate of diagnosis of allergic rhinitis in Europe. Eur Respir J. 2004; 24(5):758-64.

Bernstein DI, Schwartz G, Bernstein JA. Allergic Rhinitis: Mechanisms and Treatment. Immunol Allergy Clin North Am. 2016; 36(2):261-78.

Björnsson E, Plaschke P, Norrman E, Janson C, Lundbäck B, Rosenhall A, Lindholm N, Rosenhall L, Berglund E, Boman G. Symptoms related to asthma and chronic bronchitis in three areas of Sweden. Eur Respir J. 1994; 7:2146-2153.

Bono R, Romanazzi V, Bellisario V, Tassinari R, Trucco G, Urbino A, Cassardo C, Siniscalco C, Marchetti P, Marcon A. Air pollution, aeroallergens and admissions to pediatric emergency room for respiratory reasons in Turin, northwestern Italy. 2016. . BMC Public Health Volume 16, Issue 1, 5 August 2016, Article number 722. DOI N.

10.1186/s12889-016-3376-3 .

Brunekreef B, Hoek G, Fischer P, Spieksma FT. Relation between airborne pollen concentrations and daily cardiovascular and respiratory-disease mortality. Lancet. 2000 29;355:1517-8.

Burney PG, Luczynska C, Chinn S, Jarvis D. The European Community Respiratory Health Survey. Eur Respir J.1994; 7(5):954-960.

Burr ML, Emberlin JC, Treu R, Cheng S, Pearce NE. ISAAC Phase One Study Group. Pollen counts in relation to the prevalence of allergic rhinoconjunctivitis, asthma and atopic eczema in the International Study of Asthma and Allergies in Childhood (ISAAC). Clin Exp Allergy. 2003; 33(12):1675-80. 
381 Caillaud D, Thibaudon M, Martin S, Ségala C, Besancenot JP, Clot B, François H. French Aerobiology Network. Short-term effects of airborne ragweed pollen on clinical symptoms of hay fever in a panel of 30 patients. J Investig Allergol Clin Immunol. 2014; 24(4):249-56. hospitalization for asthma? J Allergy Clin Immunol. 2012; 129(1):228-31.

Celenza A, Fothergill J, Kupek E, Shaw RJ. Thunderstorm associated asthma: a detailed analysis of environmental factors. BMJ. 1996; 312:604-7.

Cirera L, García-Marcos L, Giménez J, Moreno-Grau S, Tobías A, Pérez-Fernández V,

Elvira-Rendeles B, Guillén JJ, Navarro C. Daily effects of air pollutants and pollen types on asthma and COPD hospital emergency visits in the industrialand Mediterranean Spanish city of Cartagena. Allergol Immunopathol (Madr). 2012; 40(4):231-7.

D'Amato G, Cecchi L, D'Amato M, Annesi-Maesano I. Climate change and respiratory diseases. Eur Respir Rev. 2014; 23(132):161-9. doi: 10.1183/09059180.00001714.

D'Amato G, Liccardi G, D'Amato M. Environmental risk factors (outdoor air pollution and 395 climatic changes) and increased trend of respiratory allergy. J Investig Allergol Clin Immunol. 2000; 10(3):123-8.

de Marco R, Accordini S, Antonicelli L, Bellia V, Bettin MD, Bombieri C, Bonifazi F, Bugiani M, Carosso A, Casali L, Cazzoletti L, Cerveri I, Corsico AG, Ferrari M, Fois AG, Lo Cascio V, Marcon A, Marinoni A, Olivieri M, Perbellini L, Pignatti P, Pirina P, Poli A, Rolla G, 152(3):255-63. 
405 Marinoni A, Panico MG, Pirina P, Villani S, Zanolin ME, Verlato G; GEIRD Study Group. 406 Trends in the prevalence of asthma and allergic rhinitis in Italy between 1991 and 2010. 407 Eur Respir J. 2012; 39(4):883-92. doi: 10.1183/09031936.00061611.

408 de Marco R, Cerveri I, Bugiani M, Ferrari M, Verlato G. An undetected burden of asthma 409 in Italy: the relationship between clinical and epidemiological diagnosis of asthma. Eur 410 Respir J. 1998; 11(3):599-605.

411 de Marco R, Poli A, Ferrari M, Accordini S, Giammanco G, Bugiani M, Villani S, Ponzio M, 412 Bono R, Carrozzi L, Cavallini R, Cazzoletti L, Dallari R, Ginesu F, Lauriola P, Mandrioli P, 413 Perfetti L, Pignato S, Pirina P, Struzzo P; ISAYA study group. Italian Study on Asthma in 414 Young Adults. The_impact_of_climate_and traffic-related NO2 on the prevalence of asthma 415 and allergic rhinitis in Italy. Clin Exp Allergy. 2002; 32(10):1405-12.

416 de Marco R, Verlato G, Zanolin ME, Bugiani M, Drane JW. Nonresponse bias in EC 417 Respiratory Health Survey in Italy. Eur Resp J 1994;7:2139-2145

418 de Marco R, Zanolin ME, Accordini S, Signorelli D, Marinoni A, Bugiani M, Lo Cascio V, 419 Woods R, Burney P. A new questionnaire for the repeat of the first stage of the European 420 Community Respiratory Health Survey: a pilot study. Eur Respir J 1999; 14: 1044-1048.

421 De Sario M, Katsouyanni K, Michelozzi P. Climate change, extreme weather events, air 422 pollution and respiratory health in Europe. Eur Respir J. 2013; 42(3):826-43.

423 Dixon J. K.. Pattern recognition with partly missing data. IEEE Transactions on Systems, 424 Man, and Cybernetics, SMC-9. 1979; 10, 617-621.

425 Eriksson NE, Holmen A. Skin prick test with standardized extracts of inhalant allergens in 4267099 adult patients with asthma or rhinitis cross sensitizations and relationship to age, sex, 427 month of birth and year of testing. J Investig Allergol Clin Immunol 1996; 6:36-46. 
428 Fix E, Hodges JL. Discriminatory Analysis - Nonparametric Discrimination: Consistency 429 Properties. USAF school of Aviation Medicine, Randolph Field Texas. 1951.

430 Jarvis D, Newson R, Lotvall J, Hastan D, Tomassen P, Keil T, Gjomarkaj M, Forsberg B, 431 Gunnbjornsdottir M, Minov J, Brozek G, Dahlen SE, Toskala E, Kowalski ML, Olze H, 432 Howarth P, Krämer U, Baelum J, Loureiro C, Kasper L, Bousquet PJ, Bousquet J, Bachert 433 C, Fokkens W, Burney P. Asthma in adults and its association with chronic rhinosinusitis: 434 the GA2LEN survey in Europe. Allergy. 2012; 67(1):91-8. doi: 10.1111/j.1398435 9995.2011.02709.x.

436 Katelaris $\mathrm{CH}$, Burke TV, Byth K. Spatial variability in the pollen count in Sydney, Australia: 437 can one sampling site accurately reflect the pollen count for a region? Ann Allergy Asthma 438 Immunol. 2004; 93(2):131-6.

439 Latorre F, Caccavari M. Airborne pollen patterns in Mar del Plata atmosphere (Argentina) 440 and its relationship with meteorological conditions. Aerobiologia 2009; 25(4):297-312.

441 Mandrioli P, Negrini M. Weather and climate in Europe. In: D'Amato G, Spieksma FT, 442 Bonini S, editors. Allergenic pollen and pollinosis in Europe. Melburn- Paris-Berlin-Vienna: 443 Blackwell Scientific Publications, 1991:3-17.

444 Ogden EC, Raynor GS, Hayes GV, Lewis DM, Haines JH. Manual for sampling airborne 445 pollen. Hafner Press, N.Y., 182 pp.; 1974.

446 Olivieri M, Verlato G, Corsico A, Lo Cascio V, Bugiani M, Marinoni A, de Marco R. Italian 447 European Community Respiratory Health Survey group. Prevalence and features of 448 allergic rhinitis in Italy. Allergy. 2002; 57(7):600-6.

449 Ownby D., Johnson C. Does exposure to dogs and cats in the first year of life influence the 450 development of allergic sensitization? Curr Opin Allergy Immunol. 2003; 517-522. 
451 Pesce G, Bugiani M, Marcon A, Marchetti P, Carosso A, Accordini S, Antonicelli L,

452 Cogliani E, Pirina P, Pocetta G, Spinelli F, Villani S, de Marco R. Geo-climatic

453 heterogeneity in self-reported asthma, allergic rhinitis and chronic bronchitis in Italy. Sci

454 Total Environ. 2016; 544:645-52. doi: 10.1016/j.scitotenv.2015.12.015. Epub 2015 Dec 10.

455 Plötz SG, Traidl-Hoffmann C, Feussner I, Kasche A, Feser A, Ring J, Jakob T, Behrendt

$456 \mathrm{H}$. Chemotaxis and activation of human peripheral blood eosinophils induced by pollen-

457 associated lipid mediators. J Allergy Clin Immunol. 2004 Jun;113(6):1152-60.

458 Rothman KJ, Greenland S, Lash TL, eds. Modern epidemiology, $3^{\text {rd }}$ edition, p. 519-20.

459 Lippincott Williams \& Wilkins, Philadelphia (US), 2008.

460 Sakaida H, Masuda S, Takeuchi K. Measurement of Japanese cedar pollen-specific IgE in 461 nasal secretions. Allergol Int. 2014; 63(3):467-73.

462 Silverberg JI, Braunstein M, Lee-Wong M. Association between climate factors, pollen 463 counts, and childhood hay fever prevalence in the United States. J Allergy Clin Immunol. $464 \quad 2015 ; 135(2): 463-9$.

465 Tobías A, Galán I, Banegas JR. Non-linear short-term effects of airborne pollen levels with 466 allergenic capacity on asthma emergency room admissions in Madrid, Spain. Clin Exp 467 Allergy. 2004; 34(6):871-8.

468 Yoshida K, Adachi Y, Akashi M, Itazawa T, Murakami Y, Odajima H, Ohya Y, Akasawa A. 469 Cedar and cypress pollen counts are associated with the prevalence of allergic diseases in 470 Japanese schoolchildren Allergy. 2013; 68(6):757-63.

471 Zanolin ME, Pattaro C, Corsico A, Bugiani M, Carrozzi L, Casali L, Dallari R, Ferrari M, 472 Marinoni A, Migliore E, Olivieri M, Pirina P, Verlato G, Villani S, Marco R; ISAYA Study 473 Group. The role of climate on the geographic variability of asthma, allergic rhinitis and 
474 respiratory symptoms: results from the Italian study of asthma in young adults. Allergy.

$475 \quad 2004 ; 59(3): 306-14$.

476 Zock JP, Heinrich J, Jarvis D, Verlato G, Norbäck D, Plana E, Sunyer J, Chinn S, Olivieri

477 M, Soon A, Villani S, Ponzio M, Dahlman-Hoglund A, Svanes C, Luczynska C; Indoor

478 Working Group of the European Community Respiratory Health Survey II. Distribution and

479 determinants of house dust mite allergens in Europe: the European Community

480 Respiratory Health Survey II. J Allergy Clin Immunol. 2006; 118(3):682-90. Epub 2006 Jul

48127.

482 
Tables

Table 1. Average number of days per year with pollens above the relative low/high concentration threshold in $2007-2008$ by study center.

\begin{tabular}{|c|c|c|c|c|c|c|c|}
\hline \multirow{2}{*}{$\begin{array}{l}\text { Pollen } \\
\text { Taxa }\end{array}$} & \multirow[b]{2}{*}{$\begin{array}{l}\text { Concentration } \\
\text { threshold }\end{array}$} & \multicolumn{3}{|l|}{ Centers } & \multirow[b]{2}{*}{ Ancona } & \multirow[b]{2}{*}{ Sassari } & \multirow[b]{2}{*}{ Salerno } \\
\hline & & Verona & Pavia & Torino & & & \\
\hline \multirow{2}{*}{ Poaceae } & low & 220 & 251 & 119 & 215 & 122 & 131 \\
\hline & high & 31 & 47 & 2 & 60 & 75 & 1 \\
\hline \multirow{2}{*}{ Urticaceae } & low & 213 & 207 & 119 & 263 & 359 & 303 \\
\hline & high & 46 & 73 & 3 & 23 & 64 & 17 \\
\hline \multirow{2}{*}{ Oleaceae } & low & 67 & 153 & 77 & 125 & 156 & 107 \\
\hline & high & 9 & 9 & 14 & 20 & 66 & 9 \\
\hline \multirow{2}{*}{ Cupressaceae } & low & 74 & 81 & 50 & 122 & 233 & 85 \\
\hline & high & 13 & 7 & 2 & 30 & 97 & 4 \\
\hline \multirow{2}{*}{ Coryloideae } & low & 105 & 116 & 79 & 107 & 82 & 92 \\
\hline & high & 3 & 10 & 1 & 15 & 0 & 2 \\
\hline \multirow{2}{*}{ Betula } & low & 114 & 90 & 71 & 40 & 0 & 38 \\
\hline & high & 16 & 17 & 1 & 7 & 0 & 0 \\
\hline \multirow{2}{*}{ Ambrosia } & low & 78 & 121 & 40 & 20 & 0 & 40 \\
\hline & high & 0 & 25 & 1 & 0 & 0 & 0 \\
\hline
\end{tabular}


Table 2. Associations ${ }^{\dagger}$ of the number of days per year with pollens above the low/high concentration threshold and pollen intensities (2007-2008) with allergic rhinitis.

\begin{tabular}{llll}
\hline \multirow{2}{*}{ Pollen Taxa } & $\begin{array}{l}\text { N. days above low } \\
\text { threshold }\end{array}$ & $\begin{array}{l}\text { N. days above high } \\
\text { threshold }\end{array}$ & $\begin{array}{l}\text { Pollen } \\
\text { intensity }\end{array}$ \\
\cline { 2 - 4 } & $\begin{array}{l}\text { OR }(95 \% \mathrm{CI}) \\
\text { per 10 days }\end{array}$ & $\begin{array}{l}\text { OR }(95 \% \mathrm{Cl}) \\
\text { per 10 days }\end{array}$ & $\begin{array}{l}\text { OR }(95 \% \mathrm{Cl}) \\
\text { per } 1000 \text { grains } / \mathrm{m}^{3}\end{array}$ \\
\hline Poaceae & $0.994(0.983-1.005)$ & $\mathbf{0 . 9 7 7}(\mathbf{0 . 9 5 8 - 0 . 9 9 7 )}$ & $\mathbf{0 . 9 8 3 ( 0 . 9 6 9 - 0 . 9 9 8 )}$ \\
\hline Urticaceae & $0.991(0.978-1.004)$ & $0.979(0.958-1.001)$ & $0.991(0.983-1.000)$ \\
\hline Oleaceae & $0.986(0.968-1.005)$ & $0.977(0.949-1.006)$ & $0.996(0.992-1.001)$ \\
\hline Cupressaceae & $0.989(0.978-1.000)$ & $0.983(0.965-1.001)$ & $\mathbf{0 . 9 9 6 ( 0 . 9 9 1 - 0 . 9 9 9 )}$ \\
\hline Coryloideae & $0.985(0.944-1.027)$ & $0.973(0.881-1.074)$ & $0.977(0.919-1.038)$ \\
\hline Betula & $1.006(0.978-1.036)$ & $0.940(0.851-1.038)$ & $0.969(0.921-1.021)$ \\
\hline Ambrosia & $1.000(0.979-1.022)$ & $0.977(0.909-1.051)$ & $0.970(0.881-1.067)$ \\
\hline
\end{tabular}

† OR were adjusted for gender, age, smoking habits, education level, heavy traffic near home, season of response, type of contact, percentile rank of response, climatic zone. OR with $p<0.05$ are in bold

Table 3. Associations ${ }^{\dagger}$ of the number of days per year with pollens above the low/high concentration threshold and pollen intensities (2007-2008) with asthma.

\begin{tabular}{llll}
\hline Pollen Taxa & $\begin{array}{l}\text { N. days above low } \\
\text { threshold }\end{array}$ & $\begin{array}{l}\text { N. days above high } \\
\text { threshold }\end{array}$ & $\begin{array}{l}\text { Pollen } \\
\text { intensity }\end{array}$ \\
\cline { 2 - 4 } & $\begin{array}{l}\text { OR }(95 \% \mathrm{Cl}) \\
\text { per 10 days }\end{array}$ & $\begin{array}{l}\text { OR }(95 \% \mathrm{Cl}) \\
\text { per 10 days }\end{array}$ & $\begin{array}{l}\text { OR }(95 \% \mathrm{Cl}) \\
\text { per 1000 grains } / \mathrm{m}^{3}\end{array}$ \\
\hline Poaceae & $0.995(0.979-1.012)$ & $1.011(0.981-1.042)$ & $1.010(0.989-1.033)$ \\
\hline Urticaceae & $1.014(0.994-1.035)$ & $1.016(0.983-1.051)$ & $1.008(0.994-1.022)$ \\
\hline Oleaceae & $0.999(0.971-1.029)$ & $1.030(0.987-1.074)$ & $1.005(0.998-1.012)$ \\
\hline Cupressaceae & $1.012(0.995-1.028)$ & $1.019(0.993-1.047)$ & $1.004(0.998-1.011)$ \\
\hline Coryloideae & $0.975(0.915-1.041)$ & $0.907(0.781-1.054)$ & $0.943(0.859-1.036)$ \\
\hline Betula & $0.988(0.946-1.032)$ & $0.992(0.850-1.157)$ & $0.998(0.920-1.082)$ \\
\hline Ambrosia & $0.987(0.954-1.021)$ & $0.954(0.849-1.071)$ & $0.937(0.803-1.093)$ \\
\hline
\end{tabular}

† OR were adjusted for gender, age, smoking habits, education level, heavy traffic near home, allergic rhinitis, season of response, type of contact, percentile rank of response, climatic zone. 


\section{Figures}

Figure 1. Crude prevalence of allergic rhinitis (A) and asthma (B) by study center and climatic zone.
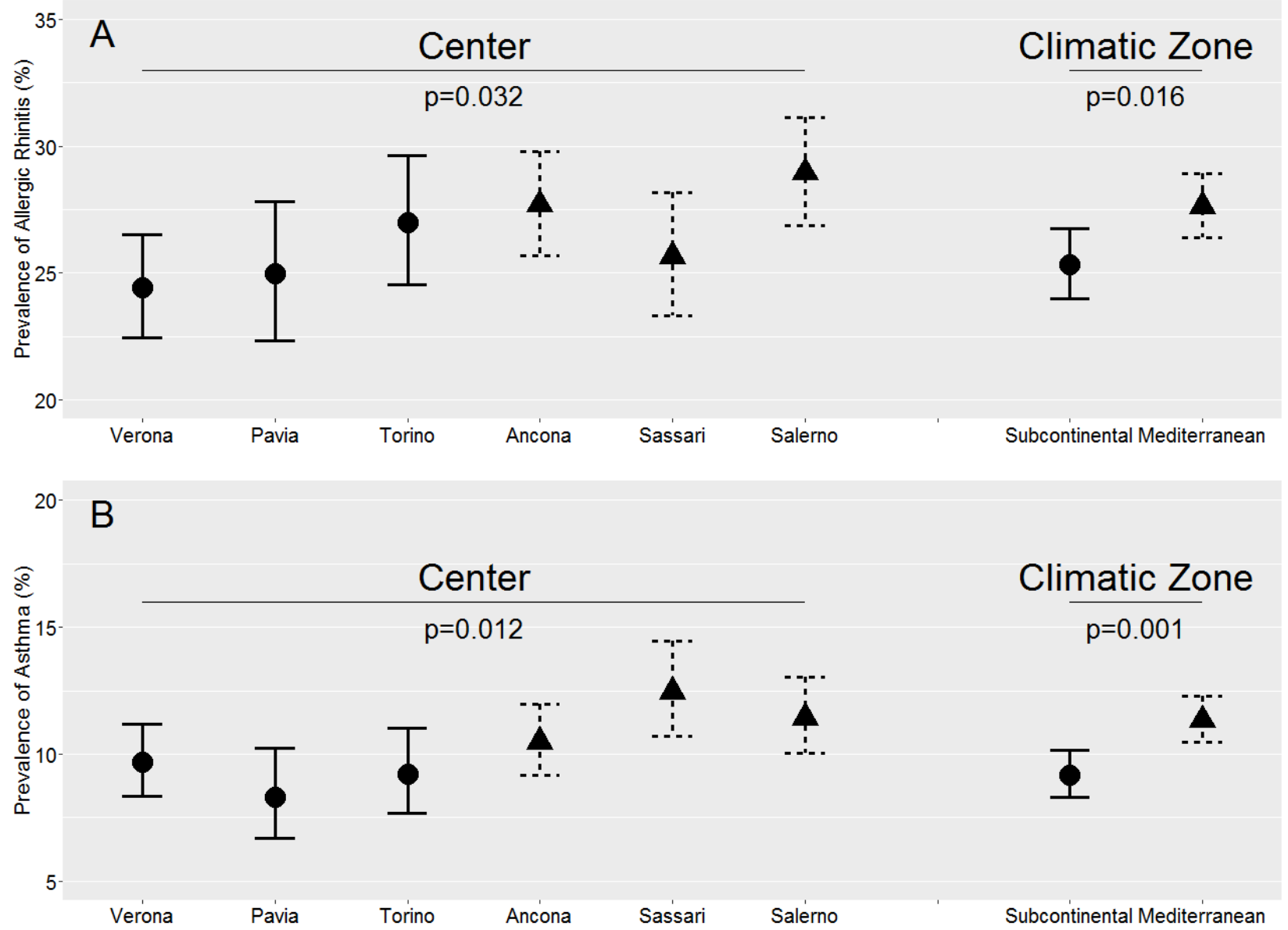
Figure 2. Average number of days per year with pollen above the low and high thresholds in 2007-2008 by climatic zone. 
Figure 3. Associations ${ }^{\dagger}$ between the number of days per year with at least one/two pollens (2007-2008) above the low/high thresholds and the prevalence of allergic rhinitis and asthma.

† OR for 10 days/year. Adjusted for gender, age, smoking habits, education level, heavy traffic near home, season of response, type of contact, percentile rank of response, climatic zone. OR for asthma are also adjusted for allergic rhinitis. 
ONLINE SUPPLEMENTARY MATERIAL

Table S1. Distribution of subjects' characteristics by study center and climatic zone.

\begin{tabular}{|c|c|c|c|c|c|c|c|c|c|c|c|}
\hline \multirow[b]{2}{*}{ Covariates } & & \multicolumn{6}{|c|}{ Centers } & \multicolumn{4}{|c|}{ Climatic zone } \\
\hline & & $\begin{array}{l}\text { Verona } \\
(n=1746)\end{array}$ & $\begin{array}{c}\text { Pavia } \\
(n=966)\end{array}$ & $\begin{array}{c}\text { Torino } \\
(n=1205)\end{array}$ & $\begin{array}{c}\text { Ancona } \\
(n=1866)\end{array}$ & $\begin{array}{c}\text { Sassari } \\
(n=1245)\end{array}$ & $\begin{array}{l}\text { Salerno } \\
(n=1806)\end{array}$ & $p^{*}$ & $\begin{array}{l}\text { Subcontinental } \\
(n=3917)\end{array}$ & $\begin{array}{l}\text { Mediterranean } \\
\quad(n=4917)\end{array}$ & $p^{*}$ \\
\hline $\begin{array}{l}\text { Male } \\
\text { gender(\%) }\end{array}$ & & 47.0 & 46.4 & 44.4 & 48.4 & 47.7 & 49.8 & 0.082 & 46.0 & 48.8 & 0.011 \\
\hline $\begin{array}{l}\text { Age (years) } \\
\text { (median; IQR) }\end{array}$ & & $\begin{array}{c}35.4 ; \\
11.5\end{array}$ & $\begin{array}{c}35.9 \\
10.6\end{array}$ & $\begin{array}{c}36.7 \\
12.1 \\
\end{array}$ & $\begin{array}{l}34.3 ; \\
11.7\end{array}$ & $\begin{array}{l}35.0 \\
11.2 \\
\end{array}$ & $\begin{array}{l}34.4 ; \\
12.3\end{array}$ & $<0.001$ & $\begin{array}{l}35.9 ; \\
11.5\end{array}$ & $\begin{array}{l}34.5 ; \\
11.8\end{array}$ & $<0.001$ \\
\hline \multirow{4}{*}{$\begin{array}{l}\text { Smoking } \\
\text { habits (\%) }\end{array}$} & non smokers & 54.4 & 58.3 & 58.4 & 58.4 & 52.7 & 60.2 & \multirow{4}{*}{$<0.001$} & 56.6 & 57.6 & \multirow{4}{*}{0.002} \\
\hline & ex-smokers & 19.1 & 17.8 & 15.5 & 15.7 & 19.6 & 11.1 & & 17.7 & 15.0 & \\
\hline & $\begin{array}{l}\text { Smokers (<15 packs- } \\
\text { year) }\end{array}$ & 16.0 & 14.1 & 15.1 & 15.0 & 14.8 & 15.4 & & 15.2 & 15.1 & \\
\hline & $\begin{array}{l}\text { smokers ( } \geq 15 \text { packs- } \\
\text { year) }\end{array}$ & 10.6 & 9.9 & 11.1 & 10.9 & 13.0 & 13.3 & & 10.5 & 12.3 & \\
\hline \multirow{3}{*}{$\begin{array}{l}\text { Level of } \\
\text { education(\%) }\end{array}$} & lower & 21.8 & 23.7 & 19.2 & 17.3 & 25.2 & 13.6 & \multirow{3}{*}{$<0.001$} & 21.5 & 20.0 & \multirow{3}{*}{$<0.001$} \\
\hline & higher & 52.4 & 51.5 & 51.3 & 59.4 & 48.2 & 52.8 & & 51.9 & 54.2 & \\
\hline & degree & 25.8 & 24.8 & 29.5 & 23.3 & 26.5 & 33.6 & & 26.7 & 27.9 & \\
\hline $\begin{array}{l}\text { Frequent/ } \\
\text { constant } \\
\text { heavy traffic } \\
\text { near home(\%) }\end{array}$ & & 39.7 & 28.4 & 53.9 & 41.2 & 37.6 & 53.7 & $<0.001$ & 41.2 & 44.8 & 0.001 \\
\hline \multirow{4}{*}{$\begin{array}{l}\text { Season of } \\
\text { response(\%) }\end{array}$} & spring & 33.9 & 57.7 & 45.6 & 59.8 & 55.2 & 21.9 & \multirow{4}{*}{$<0.001$} & 43.4 & 44.7 & \multirow{4}{*}{$<0.001$} \\
\hline & summer & 3.6 & 23.3 & 32.1 & 24.5 & 8.7 & 16.9 & & 17.2 & 17.7 & \\
\hline & autumn & 50.3 & 17.9 & 18.3 & 1.3 & 30.4 & 34.3 & & 32.5 & 20.8 & \\
\hline & winter & 12.1 & 1.1 & 4.0 & 14.4 & 5.8 & 26.9 & & 6.9 & 16.8 & \\
\hline $\begin{array}{l}\text { Type of } \\
\text { contact (\%) }\end{array}$ & postal (vs. phone) & 84.1 & 93.3 & 93.7 & 100.0 & 85.5 & 72.0 & $<0.001$ & 89.3 & 86.0 & $<0.001$ \\
\hline
\end{tabular}

IQR, interquartile range. * $\mathrm{p}$-values were computed using Pearson's Chi-square test, except for variable age where Kruskal-Wallis test

was used. 
Table S2. Average pollen intensities in 2007-2008 (grains $/ \mathrm{m}^{3}$ ) by study center and climatic zone.

\begin{tabular}{lllllllll}
\hline \multicolumn{3}{c}{ Centers } & \multicolumn{1}{c}{ Climatic zone } \\
\hline Pollen taxa & Verona & Pavia & Torino & Ancona & Sassari & Salerno & Subcontinental & Mediterranean \\
\hline Poaceae & 3642 & 5805 & 731 & 7341 & 11754 & 590 & 3393 & 6561 \\
\hline Urticaceae & 13361 & 17658 & 1581 & 7147 & 18245 & 6652 & 10867 & 10681 \\
\hline Oleaceae & 865 & 1098 & 895 & 2190 & 34973 & 1124 & 952 & 12762 \\
\hline Cupressaceae & 4988 & 3456 & 1104 & 20626 & 42302 & 2272 & 3183 & 21733 \\
\hline Coryloideae & 826 & 2440 & 555 & 2892 & 753 & 794 & 1273 & 1479 \\
\hline Betula & 3241 & 3824 & 424 & 791 & 0 & 110 & 2496 & 300 \\
\hline Ambrosia & 135 & 2003 & 136 & 62 & 0 & 21 & 758 & 27 \\
\hline
\end{tabular}


Table S3. Associations ${ }^{\dagger}$ of the number of days per year with pollens above the low/high thresholds and pollen intensities (for the years of questionnaire administration in each center) and allergic rhinitis.

\begin{tabular}{llll}
\hline \multirow{2}{*}{ Pollen Taxa } & $\begin{array}{l}\text { N. days above low } \\
\text { threshold }\end{array}$ & $\begin{array}{l}\text { N. days above high } \\
\text { threshold }\end{array}$ & $\begin{array}{l}\text { Pollen } \\
\text { intensity }\end{array}$ \\
\cline { 2 - 4 } & $\begin{array}{l}\text { OR }(95 \% \mathrm{Cl}) \\
\text { per 10 days }\end{array}$ & $\begin{array}{l}\text { OR }(95 \% \mathrm{Cl}) \\
\text { per 10 days }\end{array}$ & $\begin{array}{l}\text { OR }(95 \% \mathrm{Cl}) \\
\text { per 1000 grains } / \mathrm{m}^{3}\end{array}$ \\
\hline Poaceae & $0.998(0.987-1.009)$ & $0.980(0.956-1.004)$ & $\mathbf{0 . 9 8 0 ( 0 . 9 6 4 - 0 . 9 9 8 )}$ \\
\hline Urticaceae & $0.993(0.982-1.004)$ & $\mathbf{0 . 9 7 9 ( 0 . 9 5 9 - 0 . 9 9 9 )}$ & $\mathbf{0 . 9 8 9 ( 0 . 9 7 9 - 0 . 9 9 9 )}$ \\
\hline Oleaceae & $0.985(0.964-1.006)$ & $0.967(0.935-1.000)$ & $0.997(0.994-1.001)$ \\
\hline Cupressaceae & $0.990(0.980-1.000)$ & $0.986(0.971-1.002)$ & $\mathbf{0 . 9 9 5 ( 0 . 9 9 0 - 0 . 9 9 9 )}$ \\
\hline Coryloideae & $0.983(0.951-1.016)$ & $0.968(0.869-1.077)$ & $0.964(0.894-1.039)$ \\
\hline Betula & $0.996(0.976-1.016)$ & $0.938(0.842-1.044)$ & $0.971(0.919-1.026)$ \\
\hline Ambrosia & $1.004(0.981-1.027)$ & $0.979(0.920-1.042)$ & $0.972(0.894-1.056)$ \\
\hline
\end{tabular}

† OR were adjusted for gender, age, smoking habits, education level, heavy traffic near home, season of response, type of contact, percentile rank of response, climatic zone. OR with $p<0.05$ are in bold

Table S4. Associations ${ }^{\dagger}$ of the number of days per year with pollens above the low/high thresholds and pollen intensities (for the years of questionnaire administration in each center) and asthma.

\begin{tabular}{llll}
\hline \multirow{2}{*}{ Pollen Taxa } & $\begin{array}{l}\text { N. days above low } \\
\text { concentration } \\
\text { threshold }\end{array}$ & $\begin{array}{l}\text { N. days above high } \\
\text { concentration } \\
\text { threshold }\end{array}$ & $\begin{array}{l}\text { Pollen } \\
\text { intensity }\end{array}$ \\
\cline { 2 - 4 } & $\begin{array}{l}\text { OR }(95 \% \mathrm{Cl}) \\
\text { per 10 days }\end{array}$ & $\begin{array}{l}\text { OR }(95 \% \mathrm{Cl}) \\
\text { per 10 days }\end{array}$ & $\begin{array}{l}\text { OR }(95 \% \mathrm{Cl}) \\
\text { per } 1000 \mathrm{grains} / \mathrm{m}^{3}\end{array}$ \\
\hline Poaceae & $0.993(0.977-1.010)$ & $1.010(0.974-1.048)$ & $1.014(0.989-1.040)$ \\
\hline Urticaceae & $1.013(0.996-1.030)$ & $1.006(0.975-1.038)$ & $1.006(0.990-1.022)$ \\
\hline Oleaceae & $0.999(0.966-1.032)$ & $1.031(0.981-1.082)$ & $1.004(0.999-1.008)$ \\
\hline Cupressaceae & $1.011(0.996-1.026)$ & $1.017(0.994-1.040)$ & $1.004(0.996-1.011)$ \\
\hline Coryloideae & $1.006(0.954-1.060)$ & $0.903(0.768-1.063)$ & $0.944(0.842-1.059)$ \\
\hline Betula & $1.001(0.971-1.033)$ & $1.032(0.872-1.222)$ & $1.022(0.937-1.115)$ \\
\hline Ambrosia & $0.982(0.948-1.017)$ & $0.954(0.863-1.055)$ & $0.934(0.817-1.068)$ \\
\hline
\end{tabular}

† OR were adjusted for gender, age, smoking habits, education level, heavy traffic near home, allergic rhinitis, season of response, type of contact, percentile rank of response, climatic zone. 
Figure S1. Period when questionnaire and pollen data were collected by study center. ${ }^{\dagger}$

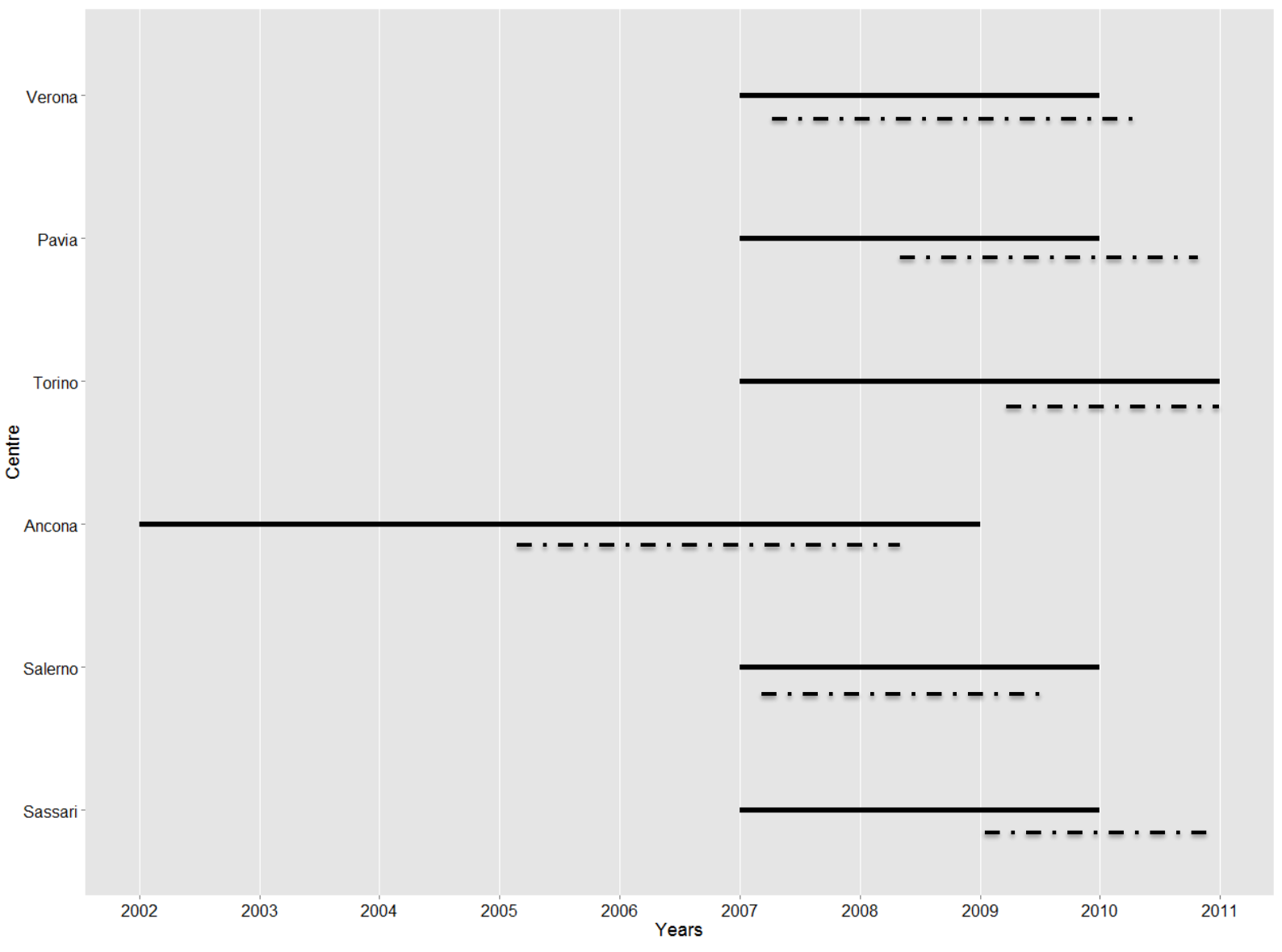

† Solid lines represent pollen data, dashed-dot lines represent the periods when questionnaires were collected. 
Figure S2. Distribution of daily ${ }^{\dagger}$ pollen concentrations in 2007-2008 (grains $\left./ \mathrm{m}^{3}\right)$ by study center.
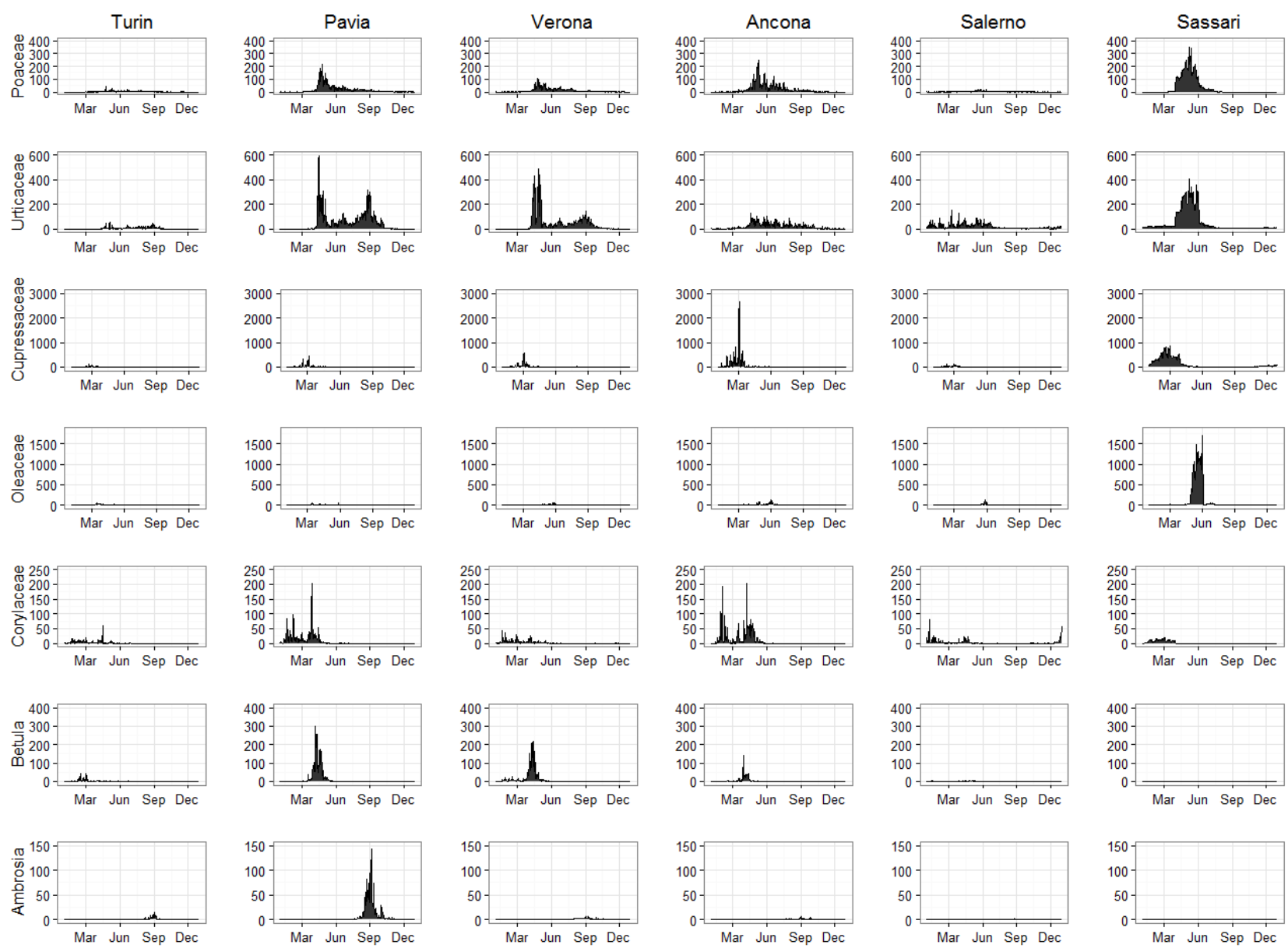

${ }^{\dagger}$ pollen concentrations for a given calendar day were averaged between 2007 and 2008 for descriptive purposes 
Figure S3. Associations ${ }^{\dagger}$ of the number of days with at least one/two pollens above the low/high thresholds (for the years of questionnaire administration in each center) with the prevalence of allergic rhinitis and asthma.

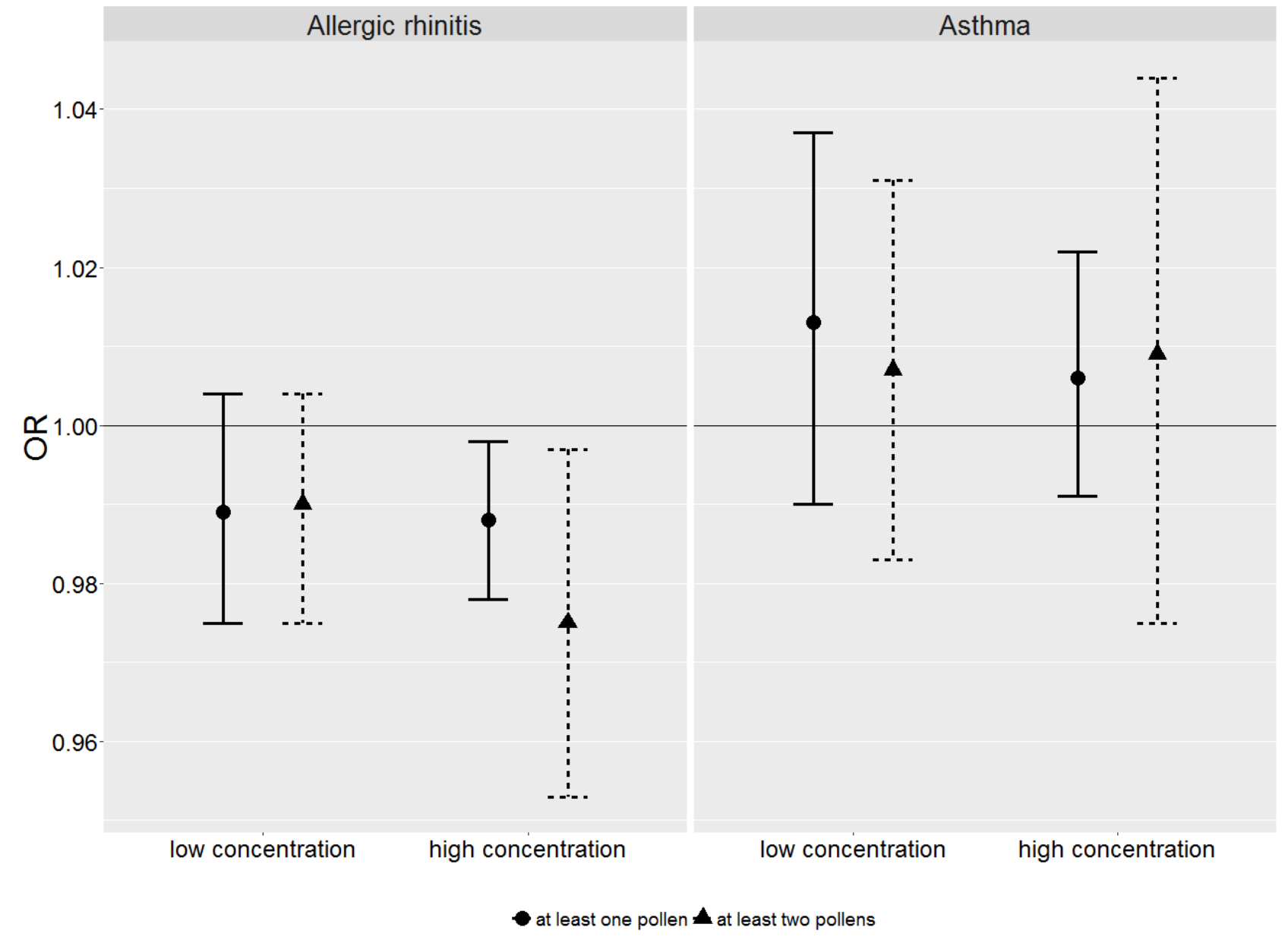

t OR for 10 days/year. Adjusted for gender, age, smoking habits, education level, heavy traffic near home, season of response, type of contact, percentile rank of response, climatic zone. OR for asthma are also adjusted for allergic rhinitis. 